\title{
Pengaruh Game "Adventure Escape From Ancient Bali" Terhadap Prestasi Belajar Siswa Kelas 3 pada Mata Pelajaran Bahasa Bali di SD Negeri 5 Sukasada Menggunakan Metode Pembelajaran Game Based Learning
}

\author{
Ida Ayu Komang Wulandari*, Nyoman Sugihartini², I Gede Mahendra \\ Darmawiguna $^{3}$
}

${ }^{123}$ Pendidikan Teknik Informatika, Universitas Pendidikan Ganesha Singaraja-Bali, Indonesia

\section{A R T I C L E I N F O}

Article history:

Received 19 January 2020

Received in revised form

10 February 2020

Accepted 12 March 2020

Available online 25 April 2020

Kata Kunci:

Quasi Eksperimen,

Adventure Escape From

Ancient Bali, Bahasa Bali,

Game Based Learning.

Keywords:

Quasi Experiments,

Adventure Escape From

Ancient Bali, Balinese

subjects, Game Based

Learning.

\section{A B S T R A K}

Penelitian ini bertujuan untuk mengetahui (1) hasil belajar yang lebih tinggi antara siswa yang belajar dengan media Game "Adventure Escape From Ancient Bali" menggunakan metode Game Based Learning dengan siswa tanpa menggunakan media Game "Adventure Escape From Ancient Bali" menggunakan metode Game Based Learning, (2) mengetahui respon siswa setelah menggunakan media Game "Adventure Escape From Ancient Bali" menggunakan metode Game Based Learning pada mata pelajaran Bahasa Bali. Jenis penelitian ini adalah eksperimen semu (quasi experiment) dengan desain Posttest-Only Control Design. Populasi penelitian mencakup seluruh siswa kelas III SD Negeri 5 Sukasada pada semester ganjil tahun ajaran 2019/2020 berjumlah 26 orang. Hasil penelitian menunjukkan (1) bahwa terdapat hasil belajar yang lebih tinggi antara siswa yang belajar dengan media Game "Adventure Escape From Ancient Bali" menggunakan metode Game Based Learning dengan siswa tanpa menggunakan media Game "Adventure Escape From Ancient Bali" menggunakan metode Game Based Learning siswa kelas III SD Negeri 5 Sukasada. Hasil analisis uji-t memperoleh nilai thitung $=$ $8,167>$ ttabel $=2,390$ untuk $\mathrm{dk}$ sebesar 24 dengan taraf signifikan $5 \%$. (2) respon siswa dari penerapan media Game "Adventure Escape From Ancient Bali" menggunakan metode Game Based Learning pada mata pelajaran Bahasa Bali adalah sangat positif dengan rata - rata skor yaitu 87,154

\section{A B S T R A C T}

This study aims to determine (1) the higher learning outcomes between the students who studied with the media Game "Adventure Escape From Ancient Bali" using the Game Based Learning method toward the students who studied without using the media Game "Adventure Escape From Ancient Bali" using the Game Based Learning method, (2) knowing the students' responses after using the media game "Adventure Escape From Ancient Bali" using the Game Based Learning method in Balinese subjects. This type of research is a quasi-experiment with a Posttest-Only Control Design. The study population included all the grade III students of SD Negeri 5 Sukasada in the first semester of the 2019/2020 school year which involved 26 people. The results showed (1) that there is the higher learning outcomes between students who studied with the media Game "Adventure Escape From Ancient Bali" using the Game Based Learning method toward the students who studied without using the media Game "Adventure Escape From Ancient Bali" using the Game Based Learning method on the third grade students of SD Negeri 5 Sukasada. The results of the t-test analysis obtained the value of thitung $=8,167>$ ttabel $=2,390$ and for $\mathrm{dk}$ is 24 with a significance level of $5 \%$. (2) the students'

\footnotetext{
Corresponding author.

E-mail addresses: Dayuwulan075@gmail.com (Ida Ayu Komang Wulandari)
} 
responses from the implementation of the game media "Adventure Escape From Ancient Bali" using the Game Based Learning method in Balinese subjects is very positive with an average score that 87,154 ..

Copyright (C Universitas Pendidikan Ganesha. All rights reserved.

\section{Pendahuluan}

Seseorang dianggap telah belajar sesuatu jika ia dapat menunjukan perubahan perilakunya. Menurut teori menyatakan bahwa belajar yang penting adalah belajar input yang dapat berupa stimulus dan output yang berupa respons. Stimulus adalah apa saja yang diberikan guru kepada siswa sedangkan respons adalah reaksi atau tanggapan pelajar terhadap stimulus yang diberikan oleh guru tersebut. Proses yang nantinya terjadi hanya dapat diamati dan juga diukur stimulus dan respons. Oleh karena itu apa yang diberikan guru (stimulus) dan apa yang dapat diterima oleh siswa (respons) harus dan mutlak dapat diamati dan juga diukur. Mengingat pelajaran yang diberikan disekolah relatif cukup banyak. Tentunya tidak semua siswa dapat merespons pelajaran dengan cepat karena antar siswa satu dengan siswa lainnya memiliki kemampuan berfikir yang berbeda-beda dan karakteristik yang berbeda juga. Salah satunya adalah dalam mata pelajaran Bahasa Bali Bahasa Bali adalah mata pelajaran yang telah dirancangkan oleh pemerintah dalam proses belajar mengajar mulai dari tingkat sekolah dasar hingga sekolah menengah atas khusus di pulau dewata. Seluruh jenjang pendidikan di Bali mulai dari SD,SMA,SMK kini diberikan pelajaran bahasa Bali yang sesuai dengan jenjang pendidikannya. Dalam hal ini pembelajaran bahasa Bali pada jenjang SD masing sangat kurang diminati bahkan dianggap pelajaran yang mudah. Namun pada kenyataannya masih banyak siswa yang kurang paham terhadap mata pelajaran ini khususnya untuk materi Nyastra Bali (menulis dan membaca bahasa aksara Bali ). SD Negeri 5 Sukasada adalah salah satu sekolah dasar yang terletak di Desa Sukasada. Sebagai salah satu sekolah dasar negeri yang berada dipinggiran Desa Sd negeri 5 Sukasada senantiasa berupaya untuk meningkatkan mutu dari segala aspek hingga dapat diharapkan nantinya akan memberikan dampak terhadap kualitas pendidikan yang siap bersaing dengan sekolah lain.

Maka dari itu sudah tentu proses belajar mengajar harus berjalan secara efektif dan efisien yang didukung oleh sarana dan prasarana yang memadai khususnya sumber belajar. Berdasarkan observasi yang peneliti lakukan dengan menggunakan teknik wawancara (lampiran 3) terhadap Kepala Sekolah SD Negeri 5 Sukasada pada tanggal 14 februari 2019 dengan Ibu Luh Kutariani,S.Pd diperoleh bahwa minat belajar siswa pada mata pelajaran bahasa Bali semakin merosot, konsep belajar yang sulit dipahami oleh siswa membuat semangat siswa untuk belajar bahasa Bali juga semakin menurun, Hal ini berakibat pada Prestasi Belajar bahasa Bali menjadi kurang baik. Nyastra Bali adalah materi awal yang didapat di kelas 3 sebelum nantinya siswa akan melanjutkan ke materi yang lain. Selain itu siswa juga merasa bosan karena dengan materi yang mereka kurang mengerti metode pembelajaran yang guru berikan juga masih cenderung membuat siswa menjadi bosan dan akhirnya mengantuk dalam proses belajar. Tapi di sisi lain siswa sekolah dasar cenderung masih suka untuk bermain dan harus dipaksakan untuk menguasai materi yang dirasa mereka sulit untuk dimengerti.

Game adalah salah satu alternative bagi siswa sekolah dasar yang digunakan dalam proses pembelajaran. Sebuah penelitian sebelumnya yang dilakukan oleh (Amelia, 2012 ) dengan judul "Pengaruh Game Edukatif RekenTest terhadap Prestasi Belajar Matematika Sistem Operasi Hitung Siswa Sekolah Dasar Kelas III" menyatakan bahwa pembelajaran dengan menggunakan game berpengaruh secara signifikan terhadap Prestasi Belajar siswa saat menggunakan game daripada saat pembelajaran menggunakan media kertas.

Penelitian sejenis yang dilakukan oleh (Wahyudi, 2017) dengan judul "Pengaruh Game Labirin Matematika Berstrategikan Student Teams Achievement Division (STAD) Terhadap Prestasi Belajar Siswa SD Negeri 1, 2, 5 Banyuasri" menyatakan bahwa pembelajaran dengan menggunakan game ini dapat meningkatakan Prestasi Belajar siswa secara signifikan, dapat dilihat dari rata-rata skor respon siswa sebesar 98,02.

Sebuah penelitian lain oleh (Syahsiah, 2012) yang berjudul "Pengaruh Penggunaan Permainan Monopoli Sebagai Media Pengajaran Matematika terhadap Minat belajar Siswa Sekolah Dasar" menyatakan peningkatan Prestasi Belajar menggunakan media permainan monopoli matematika lebih tinggi daripada rata-rata minat belajar matematika siswa yang tidak menggunakan media tersebut. Selain itu juga menjelaskan bahawa video, foto maupun game yang tepat dapat memberikan dampak yang positif 
pada siswa, bahkan dapat dirancang khusus sebagai media pembelajaran yang efektif bagi perkembangan kognitif, motorik maupun sosial-emosional [1]. Diharapkan dengan adanya game motivasi dan minat siswa untuk belajar bahasa Bali menjadi semakin tinggi.

Dengan masalah yang ada dan juga pemanfaatkan perkembangan teknologi. Peneliti memanfaatkan sebuah aplikasi game yang sebelumnya telah dikembangkan berjudul "escape form ancient Bali", game adventure barbasis edukasi dan budaya oleh Detut Indra S.A.N game ini merupakan game bergenre adventure yang berbasis pada edukasi dan juga budaya. Dengan berisikan materi pengenalan budaya, dan juga memberikan materi pengenalan aksara Bali. Namun belum dilakukan sebuah penelitian untuk mengetahui Prestasi Belajar siswa

\section{Metode}

Penelitian ini menggunakan desain penelitian eksperimen semu (quasi experimental) dengan pola dasar post test only control group design. Pada penelitian ini diberikan perlakuan yang berbeda kepada kedua kelas yaitu kelas eksperimen dengan jumlah siswa 13 orang dan kelas kontrol dengan jumlah siswa 13 orang

Kelas eksperimen diberikan perlakuan berupa Media Game Adventure Escape From Ancient Bali dengan metode pembelajaran Game Based Learning dan kelas kontrol tanpa menggunakan Media Game Adventure Escape From Ancient Bali dengan metode pembelajaran Game Based Learning saat proses pembelajaran berlangsung.

Sebelum menentukan kelas yang akan digunakan sebagai sampel, peneliti melakukan uji kesetaraan terlebih dahulu dengan menggunakan uji-t. Metode pengumpulan data yang digunakan dalam penelitian ini adalah metode tes. Metode tes digunakan untuk mengetahui hasil belajar Bahasa Bali Materi Nystra Bali siswa dengan menggunakan tes essay dan metode angket digunakan untuk mengetahui respon siswa terkait dengan penggunaan Media Game Adventure Escape From Ancient Bali dengan metode pembelajaran Game Based Learning penggunaan metode angket karena angket atau kuesioner merupakan suatu teknik atau cara pengumpulan data secara tidak langsung (peneliti tidak langsung bertanya-jawab dengan responden) [7]. Adapun Metode dan Instrumen Pengumpulan Data yang digunakan dalam penelitian ini dapat disajikan pada Tabel 1 berikut.

Tabel 1 Metode dan Instrumen Pengumpulan Data

\begin{tabular}{|c|c|c|c|c|}
\hline Jenis Data & Sumber Data & Metode & Instrumen & Waktu \\
\hline $\begin{array}{l}\text { Hasil Belajar bahasa bali materi } \\
\text { nystra bali }\end{array}$ & $\begin{array}{l}\text { Siswa kelompok } \\
\text { eksperimen dan } \\
\text { kelompok } \\
\text { kontrol }\end{array}$ & Tes & $\begin{array}{l}\text { Tes hasil belajar } \\
\text { berupa essay }\end{array}$ & $\begin{array}{l}\text { Setelah proses } \\
\text { pembelajaran }\end{array}$ \\
\hline Respon siswa & $\begin{array}{l}\text { Siswa kelas } \\
\text { eksperimen }\end{array}$ & Angket & $\begin{array}{l}\text { Angket respon } \\
\text { siswa }\end{array}$ & $\begin{array}{l}\text { Setelah proses } \\
\text { pembelajaran }\end{array}$ \\
\hline
\end{tabular}

Perangkat pembelajaran dan instrument penelitian dilakukan pengujian terlebih dahulu untuk mendapat gambaran secara empirik apakah perangkat dan instrumen layak digunakan dalam penelitian. Validasi perangkat pembelajaran dilakukan dengan menentukan validitas isi perangkat pembelajaran, sedangkan validiasi instrument penelitian dilakukan dengan menentukan validitas isi tes, reliabilitas tes, indeks kesukaran butir, dan indeks daya beda. Validitas tes ini ditinjau dari validitas isi dan validitas konstruk. Untuk memperoleh tujuan dari proses analisis, data terlebih dahulu dianalisis dengan menggunakan uji validitas tes dan reliabilitas tes.

A. Validitas Isi

Pengujian validitas isi instrument penelitian dilakukan dengan mempertimbangkan 2 orang ahli isi. Teknik pengujian validitas isi yang digunakan yaitu formula Gregory.

B. Validitas Konstruk

Validitas tes yang bersifat dikotomi seperti jenis tes objektif pilihan ganda, benar salah, atau menjodohkan dihitung dengan menggunakan rumus [8]:

$$
\mathbf{r}_{\mathbf{x y}}=\frac{\mathbf{N} \sum \mathbf{X Y}-\left(\sum \mathbf{X}\right)\left(\sum \mathbf{Y}\right)}{\sqrt{\left\{\mathbf{N} \sum \mathbf{X}^{2}-\left(\sum \mathbf{X}\right)^{2}\right\}\left\{\mathbf{N} \sum \mathbf{Y}^{2}-\left(\sum \mathbf{Y}\right)^{2}\right\}}}
$$


Keterangan :

Rxy = koefisien korelasi product moment

$\mathrm{X} \quad$ = skor yang diperoleh siswa pada butir yang akan diuji validitasnya

$\mathrm{Y} \quad=$ skor total yang diperoleh

$\mathrm{N} \quad=$ banyak responden atau peserta

C. Uji Reliabilitas

Pengujian reliabilitas pada penelitian ini menggunakan formula Alpha Cronbach :

$$
\mathbf{r}_{11}=\left(\frac{\mathrm{k}}{\mathrm{k}-1}\right)\left(1-\frac{\sum \sigma_{\mathrm{b}}{ }^{2}}{\sum \sigma_{\mathrm{t}}{ }^{2}}\right)
$$

Keterangan:

$\mathrm{r}_{11}=$ reliabilitas instrument

$\mathrm{K}=$ banyaknya butir pertanyaan

$\sum \sigma_{\mathrm{b}}{ }^{2}=$ jumlah varians butir

$\sigma_{\mathrm{t}}^{2} \quad=$ varian total

D. Uji Indeks Kesukaran Butir

Taraf kesukaran test adalah kemampuan tes tersebut dalam menjaring banyaknya subjek peserta tes yang dapat mengerjakan dengan betul. Jika banyak subjek peserta tes yang dapat menjawab dengan benar maka taraf kesukaran test

$$
\mathbf{I}=\frac{\sum \mathbf{U}+\sum \mathbf{L}-\left(2 \mathbf{N} * \mathbf{S}_{\text {min }}\right)}{2 \mathbf{N}\left(\mathbf{S}_{\text {maks }}-\mathbf{S}_{\text {min }}\right)}
$$

Keterangan:

$$
\begin{aligned}
& \sum \mathrm{U}=\text { total skor kelompok atas } \\
& \sum L_{=}=\text {total skor kelompok bawah } \\
& \mathrm{S}_{\text {min }}=\text { skor minimum butir } \\
& \mathrm{S}_{\text {maks }}=\text { skor maksimum butir } \\
& \mathrm{N}=\text { banyak peserta tes }
\end{aligned}
$$

E. Uji Indeks Daya Beda Butir

analisis daya pembeda adalah pengkajian butir-butir soal yang dimaksudkan untuk mengetahui kesanggupan butir-butir tes untuk membedakan siswa yang tergolong mampu dengan siswa yang tergolong tidak mampu. Dapat di dapatkan dengan rumus :

$$
\mathrm{d}=\frac{(\mathrm{n}-1)\left(\mathrm{N}^{2}-\sum \mathrm{f}_{\mathrm{i}}^{2}\right)}{\mathrm{nN}^{2}}
$$

Keterangan:

d : Indeks daya beda

$\mathrm{N} \quad$ : banyak peserta tes

fi : frekuensi pada tiap tiap skor

n : banyak butir

\section{Hasil dan pembahasan}

\section{Hasil Penelitian}

Penelitian eksperimen ini bertujuan untuk mencari pengaruh penggunaan Media Game Adventure Escape From Ancient Bali dengan metode pembelajaran Game Based Learning terhadap Prestasi belajar bahasa bali materi nyastra bali siswa kelas III, setelah diberikan perlakuan, selanjutnya diberikan tes akhir (posttest) pada kelompok eksperimen dan kelompok kontrol dengan tujuan untuk mengetahui hasil belajar siswa setelah diberi perlakuan.

Analisis dari hasil penelitian didapat bahwa rata-rata posttest hasil belajar bahasa bali materi nyastra bali yang dicapai siswa pada kelompok eksperimen yang menggunakan Media Game Adventure 
Escape From Ancient Bali dengan metode pembelajaran Game Based Learning pada proses pembelajaran adalah sebesar 23,769 berdasarkan jumlah skor total pada kelas eksperimen dengan varians 1,359 dan standar deviasi sebesar 1,166. frekuensi dari data hasil belajar Bahasa bali materi nyastra bali kelas eksperimen seperti pada Tabel 2 :

Tabel 2 Kategori Data Hasil Belajar Bahasa Bali Kelas Eksperimen

\begin{tabular}{|c|c|c|c|}
\hline Rentangan Skor & Kategori & Frekuensi & Persentase \\
\hline $22,75 \leq X \leq 28$ & Sangat Tinggi & 11 & 84,62 \\
\hline $19,25 \leq X<22,75$ & Tinggi & 2 & 15,38 \\
\hline $15,75 \leq X<19,25$ & Sedang & 0 & 0 \\
\hline $12,25 \leq X<15,75$ & Rendah & 0 & 0 \\
\hline $7 \leq X<12,25$ & Sangat Rendah & 0 & 0 \\
\hline \multicolumn{2}{|c|}{ Jumlah } & 13 & 100 \\
\hline
\end{tabular}

Setelah didapatkan frekuensi secara umum dapat dilihat data hasil belajar Bahasa bali materi nyastra bali kelas eksperimen dapat disajikan dalam bentuk histogram seperti Gambar 1 :

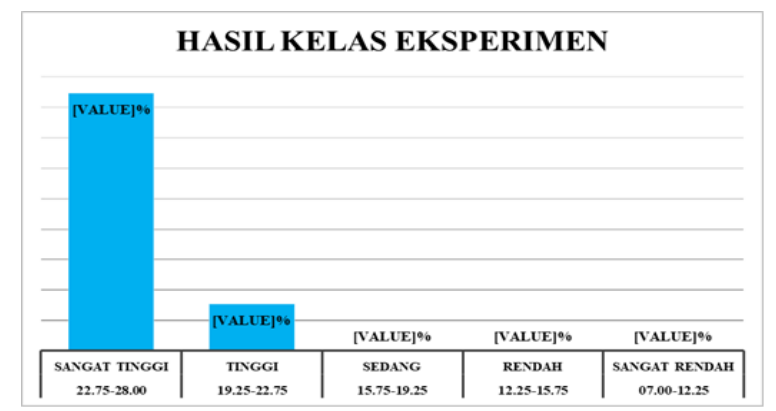

Gambar 1. Histogram Hasil Belajar Kelompok Eksperimen

Dapat dijelaskan pada gambar 1 bahwa hasil belajar Bahasa bali materi nyastra bali kelas eksperimen sebanyak $84,62 \%$ berkategori sangat tinggi, 15,38\% berkatagori tinggi dan tidak ada siswa yang memiliki hasil belajar Bahasa bali materi nyastra bali berkategori sedang, rendah dan sangat rendah.

Hasil analisis skor posttest kelompok kontrol mendapat rata-rata sebesar 19,846 berdasarkan jumlah skor total pada kelas kontrol. Varians sebesar 1,641 dan standar deviasi sebesar 1,281. frekuensi dari data hasil belajar Bahasa bali materi nyastra bali kelas eksperimen seperti pada Tabel 3 :

Tabel 3 Kategori Data Hasil Belajar Bahasa Bali Kelas Kontrol

\begin{tabular}{|c|c|c|c|}
\hline Rentangan Skor & Kategori & Frekuensi & Persentase \\
\hline $22,75 \leq X \leq 28$ & Sangat Tinggi & 0 & 0 \\
\hline $19,25 \leq X<22,75$ & Tinggi & 8 & 61,54 \\
\hline $15,75 \leq X<19,25$ & Sedang & 5 & 38,46 \\
\hline $12,25 \leq X<15,75$ & Rendah & 0 & 0 \\
\hline $7 \leq X<12,25$ & Sangat Rendah & 0 & 0 \\
\hline \multicolumn{2}{|c|}{ Jumlah } & 13 & 100 \\
\hline
\end{tabular}

Setelah didapatkan frekuensi secara umum dapat dilihat data hasil belajar Bahasa bali materi nyastra bali kelas eksperimen dapat disajikan dalam bentuk histogram seperti Gambar 8 : 


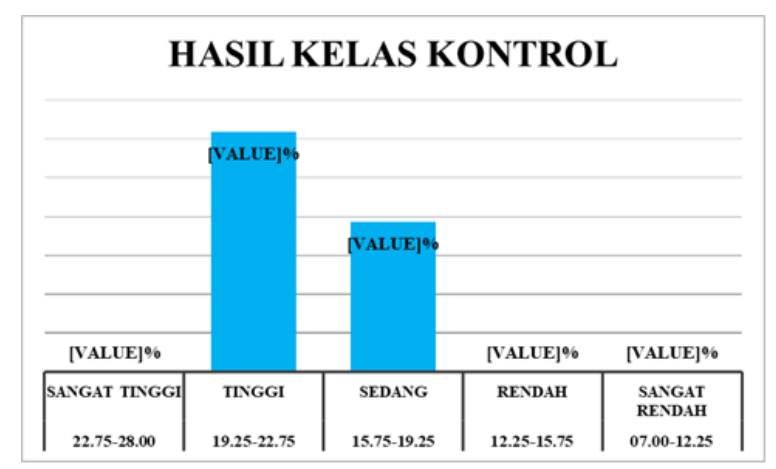

Gambar 2 Histogram Hasil Belajar Kelompok kontrol

Dapat dijeaskan pada gambar 8 bahwa hasil belajar Bahasa bali materi nyastra bali kelas kontrol sebanyak 61,54\% berkategori tinggi, sebanyak 38,46\% berkatagori sedang, dan tidak ada siswa yang hasil belajarnya sangat tinggi, rendah dan sangat rendah.

Perhitungan uji prasyarat dilakukan dalam dua buah uji yakni normalitas dan homogenitas. Uji normalitas data hasil belajar dilakukan dengan dua jenis perhitungan yaitu dengan menggunakan Ms. Excel 2007 dan menggunakan SPSS 16.0. Hasil belajar kelompok eksperimen dengan melakukan perhitungan pada Ms. Excel 2010 mendapat hasil Thitung sebesar 0.1938 dan kelompok kontrol mendapat hasil sebesar 0.221 dengan $\mathrm{dk}=(13-1)=12$ dan taraf signifikan $5 \%$ adalah sebesar 0.3767 , dengan demikian data kelas eksperimen dan kelas kontrol dinyatakan berdistribusi normal karena Thitung < Ttabel yang ditunjukkan pada Tabel 4

Tabel 4 Rangkuman Hasil Uji Normalitas dengan Ms. Excel 2010

\begin{tabular}{llll}
\hline \multicolumn{1}{c}{ Sampel } & \multicolumn{1}{c}{ Thitung } & Ttabel & Keterangan \\
\hline Kelompok eksperimen & 0.1938 & 0.3767 & Normal \\
Kelompok Kontrol & 0.221 & 0.3767 & Normal \\
\hline
\end{tabular}

Selain menggunakan Ms. Excel 2010 perhitungan uji normalitas juga dilakukan dengan menggunakan SPSS 16.0 dengan hasil seperti pada Tabel 5

Tabel 5. Rangkuman Hasil Uji Normalitas dengan Ms. Excel 2010

\begin{tabular}{llll}
\hline \multicolumn{1}{c}{ Kelompok } & Kolmogorov-smrnov & Sig & Keterangan \\
\hline Kelompok eksperimen & .195 & 0.05 & Normal \\
Kelompok Kontrol & .081 & 0.05 & Normal \\
\hline
\end{tabular}

Hasil uji normalitas menggunakan SPSS 16.0 menunjukkan bahwa angka signifikan kelompok eksperimen dan kelompok kontrol lebih besar dari 0,05 sehingga kedua data hasil belajar tersebut dikatakan berdistribusi normal.

Perhitungan selanjutnya adalah uji homogenitas menggunakan uji-f sehingga mendapat hasil Fhitung = 1,207 Derajat kebebasan (dk) untuk pembilang adalah 13-1=12 dan derajat kebebasan (dk) untuk penyebut adalah 13-1=12 dengan taraf signifikan 5\%, maka diperoleh Ftabel = 2,686. Dalam hal ini berlaku ketentuan, bila harga Fhitung lebih kecil atau sama dengan Ftabel (Fhitung $\leq$ Ftabel), maka H0 diterima dan $\mathrm{H} 1$ ditolak sehingga varians dikatakan homogen. Selain itu, uji homogenitas juga dilakukan dengan SPSS 16.0 dengan hasil 0,086 yang berarti homogeny karena lebih besar dari taraf signifikan yaitu 0,05 .

Berdasarkan data yang diperoleh kelompok eksperimen dan kelompok kontrol telah berdistribusi normal dan data homogen maka dilanjutkan dengan melakukan uji hipotesis dengan menggunakan uji-t. Uji-t dapat dihitung dengan menggunakan Ms. Excel 2010 dan SPSS 16.0. Uji-t dengan Ms. Excel 2010 dihitung menggunakan rumus Polled Varians sebagai berikut.

$$
\mathrm{t}=\frac{\overline{\mathrm{x}}_{1}-\overline{\mathrm{X}}_{2}}{\sqrt{\frac{\left(\mathrm{n}_{1}-1\right) \mathrm{s}_{1}^{2}+\left(\mathrm{n}_{2}-1\right) \mathrm{s}_{2}^{2}}{\mathrm{n}_{1}+\mathrm{n}_{2}-2}\left(\frac{1}{\mathrm{n}_{1}}+\frac{1}{\mathrm{n}_{2}}\right)}}
$$




$$
\begin{aligned}
& t=\frac{23,77-19,85}{\sqrt{\frac{(13-1) \times 1,359+(13-1) \times 1,641}{13+13-2}\left(\frac{1}{13}+\frac{1}{13}\right)}} \\
& t=8,167
\end{aligned}
$$

Berdasarkan perhitungan tersebut memperoleh thitung sebesar 8,167. Nilai ttabel dengan $\mathrm{dk}=$ 24 dengan taraf signifikan $5 \%$ adalah sebesar 2,390. Berdasarkan perhitungan uji-t diperoleh thitung>ttabel $(8,167>2,390)$ maka H0 ditolak, berarti H1 diterima.

Berdasarkan hal ini dapat diartikan bahwa terdapat hasil belajar yang lebih tinggi antara siswa yang menggunakan media Game Adventure Escape From Ancient Bali dan metode pembelajaran Game Based Learning dengan siswa yang belajar menggunakan media pembelajaran LKS pada mata pelajaran Bahasa Bali kelas 3 di SD Negeri 5 Sukasada. Uji-t juga dihitung dengan menggunakan SPSS 16.0 dengan hasil sebagai berikut.

Tabel 6. Uji Hipotesis dengan SPSS 16.0

\begin{tabular}{ccccc} 
& & \multicolumn{3}{c}{ t-test for Equality of Means } \\
& & $\mathrm{t}$ & Df & $\begin{array}{c}\text { Sig. } \\
\text { (2tailed) }\end{array}$ \\
\hline \multirow{2}{*}{ Nilai } & Equal variances assumed & 8.167 & 24 & 0.000 \\
& Equal variances not assumed & 8.167 & 23.790 & 0.000 \\
\hline
\end{tabular}

Hasil uji hipotesis dengan uji-t menggunakan SPSS 16.0 didapatkan nilai signifikan sebesar 0,000. Oleh karena itu probabilitas signifikan < 0,05, maka H1 diterima, sehingga dapat dikatakan bahwa terdapat hasil belajar yang lebih tinggi antara siswa yang menggunakan media Game Adventure Escape From Ancient Bali dan metode pembelajaran Game Based Learning dengan siswa yang belajar menggunakan media pembelajaran LKS pada mata pelajaran Bahasa Bali kelas 3 di SD Negeri 5 Sukasada

Pembahasan

a. Prestasi Belajar

Berdasarkan seluruh penemuan yang diperoleh baik dari analisis deskriptif maupun berdasarkan hasil analisis uji-t, maka dapat diambil suatu keputusan bahwa media Game Adventure Escape From Ancient Bali dan metode pembelajaran Game Based Learning memberikan pengaruh yang lebih baik dibandingkan dengan pembelajaran tanpa menggunakan media Game Adventure Escape From Ancient Bali dan metode pembelajaran Game Based Learning

Setelah dilakukan perlakuan pada kelas eksperimen dengan meggunakan media Game Adventure Escape From Ancient Bali dan metode pembelajaran Game Based Learning disebarkan pula angket respon siswa yang mendapatkan rata rata skor respon sswa sebesar 87,154 yang berkategori sangat positif

Jumlah pertanyaan angket respon siswa adalah 20 item. Berdasarkan hal tersebut dapat ditentukan skor tertinggi ideal adalah 100 dan skor terendah ideal adalah 20. Respon siswa dikategorikan menjadi 5 yaitu sangat positif, positif, cukup positif, kurang positif, dan sangat kurang positif.

Frekuensi dari data skor respon siswa terhadap penggunaan media Game Adventure Escape From Ancient Bali dan metode pembelajaran Game Based Learning dapat dilihat pada Tabel 7.

Tabel 7 Sebaran Skor Respon Siswa

\begin{tabular}{cccc}
\hline \multicolumn{1}{c}{ Rentang Skor } & Katagori & Frekuensi & Persentase (\%) \\
\hline $80 \leq \bar{X} \leq 100$ & Sangat Positif & 13 & 100 \\
$67 \leq \bar{X}<80$ & Positif & 0 & 0 \\
$53 \leq \bar{X}<67$ & Cukup Positif & 0 & 0 \\
$40 \leq \bar{X}<53$ & Kurang Positif & 0 & 0 \\
$20 \leq \bar{X}<40$ & Sangat Kurang Positif & 0 & 0 \\
& & $\mathbf{1 3}$ & $\mathbf{1 0 0}$ \\
\hline
\end{tabular}


Setelah didapatkan frekuensi secara umum dapat dilihat data skor respon siswa terhadap penggunaan media Game Adventure Escape From Ancient Bali dan metode pembelajaran Game Based Learning dapat disajikan dalam bentuk histogram seperti Gambar 9 :

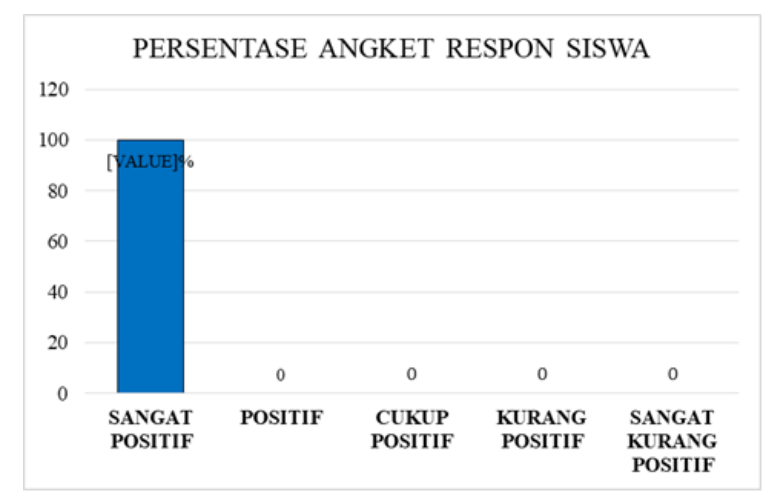

Gambar 3 Histogram Respon Siswa

Dapat diketahui bahwa respon siswa terhadap media Game Adventure Escape From Ancient Bali dan metode pembelajaran Game Based Learning sebanyak 100\% berkategori sangat positif serta tidak ada respon siswa yang berkategori positif, cukup positif, kurang positif dan sangat kurang positif.

Berdasarkan hasil analisis respon siswa terhadap media Game Adventure Escape From Ancient Bali dan metode pembelajaran Game Based Learning dapat digambarkan bahwa siswa sangat senang dan sangat tertarik menggunakan media tersebut dilihat dari rata-rata skor respon siswa yaitu 87,154 yang berada dalam berkatagori sangat positif.

\section{a. Prestasi Belajar}

Berdasarkan seluruh penemuan yang diperoleh baik dari analisis deskriptif maupun berdasarkan hasil analisis uji-t, maka dapat diambil suatu keputusan bahwa media Game Adventure Escape From Ancient Bali dan metode pembelajaran Game Based Learning memberikan pengaruh yang lebih baik dibandingkan dengan pembelajaran tanpa menggunakan media Game Adventure Escape From Ancient Bali dan metode pembelajaran Game Based Learning

Berdasarkan pertimbangan-pertimbangan teoritik dan operasional, maka implikasi dari penelitian ini jika dilihat dari teori konstruktivisme adalah proses belajar dan pembelajaran dikelas siswa harus terlibat aktif dan siswa menjadi pusat kegiatan belajar dan pembelajaran di kelas. Siswa harus dapat mengaplikasikan ide-ide mereka sendiri, siswa harus mengkonstruksikan pengetahuan dibenak mereka sendiri sehingga hasil belajar dicapai dengan lebih baik. Berdasarkan hal ini bahan atau media ajar yang dapat digunakan untuk mencapai hasil belajar dengan lebih baik adalah Media Game "Adventure Escape From Ancient Bali" dengan matode GBL (Game based Learning)

\section{Simpulan dan saran}

Berdasarkan hasil penelitian dan pembahasan, dapat dikemukakan beberapa simpulan. Adapun simpulan yang akan dikemukakan dalam penelitian ini adalah sebagai berikut, Terdapat hasil belajar yang lebih tinggi antara siswa yang belajar Media Game "Adventure Escape From Ancient Bali" dan metode pembelajaran GBL (Game Based Learning) Belajar dan siswa yang tanpa menggunakan Media Game "Adventure Escape From Ancient Bali" dan metode pembelajaran GBL (Game Based Learning) pada mata pelajaran Bahasa Bali materi Nyastra Bali siswa kelas III SD Negeri 5 Sukasada. Dilihat rata-rata hasil belajar kelompok eksperimen dengan penerapan Media Game "Adventure Escape From Ancient Bali” dan metode pembelajaran GBL (Game Based Learning) adalah 23,769 sedangkan rata-rata posttest untuk kelompok kontrol sebesar. Berdasarkan rata-rata hasil belajar tersebut maka dapat disimpulkan bahwa hasil belajar lebih tinggi terdapat pada siswa yang menggunakan media Game Adventure Escape From Ancient Bali dan metode pembelajaran Game Based Learning, (2) Hasil dari analisis respon siswa dari penerapan Media Game "Adventure Escape From Ancient Bali" dan metode pembelajaran GBL (Game Based Learning) pada mata pelajaran Bahasa Bali materi Nyastra Bali dilihat dari rata - rata skor respon siswa sebesar 87,154 adalah termasuk dalam kategori sangat positif. 


\section{Daftar Rujukan}

Gregory, R. J. (2000). Pyicological Testing: History, Principles, and Applications Third Edition. Toronto: Allyn and Bacon.

Hamalik, O. (2001). Proses Belajar Mengajar. Jakarta: PT Bumi Aksara.

PRENSKY, M. (2003). Game-Based Learning . New York : Games2train.

Teed, R. (2015 ). Game-based learning. Education .

Rahman, M., \& Amri, S. (2014). Model Pembelajaran ARIAS Terintegratif. Jakarta: PT. Prestasi Pustakarya.

Sadiman, A. R, 2005. Media Pendidikan. Jakarta: PT. Raja Grafindo Persada.

Sugihartini, N. (2016). Strategi Pembelajaran Pendekatan Inovatif Disertai dengan aplikasi Pembelajaran). Singaraja: Undiksha Press.

Sudaryono, Margono, G., \& Rahayu, W. (2013). Pengembangan Instrumen Penelitian Pendidikan. Yogyakarta: Graha Ilmu. 